\title{
The Achaeans and the Europeans: An Interdisciplinary Comparison of Federations
}

\author{
Emmanouil M. L. Economou (Corresponding author) \\ Department of Economics, University of Thessaly, Greece \\ E-mail: emmoikon@uth.gr \\ Nicholas C. Kyriazis \\ Department of Economics, University of Thessaly, Greece \\ E-mail: nkyr@uth.gr
}

Received: February 23, 2016 Accepted: April 6, 2016 Published: August 31, 2016

doi:10.5296/ijssr.v4i2.9076 URL: http://dx.doi.org/10.5296/ijssr.v4i2.9076

\begin{abstract}
In the present essay we undertake the comparison of two federations, the ancient Greek Achaean with the European Union (EU). We present the institutional (political and economic) set up of the Achaean federation and then we proceed to a comparison between them under a specific set of criteria and discuss differences and similarities. We conclude offering some insights concerning democratisation and cohesion based on the institutional organization of the ancient Greek federation. We found that some of the basic Achaean federal institutions could be served as a benchmark for the further promotion of democratic procedures and social cohesion in economic terms in the European Union.
\end{abstract}

Keywords: Achaean Federation, cohesion, democratization, European Union, federal criteria, federations

\section{Introduction}

During the May 2014 elections for the European Parliament, growing citizens' dissatisfaction with the EU was manifested and entailed the rise of euroscepticism in all $28 \mathrm{EU}$ member-states. In France and Great Britain anti-European parties came first, while even in Germany, which is probably the state which actually benefits the most from the EU and the European Monetary Union (EMU), the anti-European political party Alternative für Deutschland took 7 out of Germany's 96 seats for the European Parliament (2.070.014 votes). 
Europeans consider more and more that there is a grave democratic deficit and thus legitimization in the EU, and also a lack of solidarity and cohesion. Thus, growing euroscepticism. As we will show, these perceptions are unfortunately correct. The discussion of federations and democracy issues are current in most countries, and dissatisfaction is rising in many of them. This discussion started in ancient Greek democracy, both in theory through the works of Plato's Republic (Book VI) Aristotle's Politics, (Book 6, 1316b-1323a) Thucydides' History, (Funeral Oration), Xenophon's, The Polity of the Athenians, ch. 1, Polybius' Histories, (Book 2), and Plutarch's Life of Aratus (Book XI) (Note 1) and in practice, culminating in the great Greek "proto-federations" (Note 2), most prominent among them the Boeotian (central Greece), Aetolian (western and central Greece) and the Achaean (Peloponnesian peninsula).

Many modern authors continue to call them "leagues". But as it will become clear in the following analysis, this term must is inappropriate since the term "league" is almost a synonym of "alliance". The Achaean case, which we analyse here in more detail, consists a political entity which is much more than a mere alliance. Thus, we will define them as "proto-federations", "proto" in the Greek sense of "first", and not in the sense of less-developed. These "proto-federations" were successful and long lasting (about 250 years, till the Roman conquest of Greece) and were an inspiration for later ones, such as the American Founding Fathers (Note 3). They solved efficiently the main federation problems as, for example, in establishing a balance based on principles between the central authority and the autonomy of constituent city-states (Note 4).

In the next section we present briefly the institutional setup of the Achaean federation. Then, we make a comparative presentation of three federal states, the Achaean federation with the European Union. For the evaluation we make a use of a specific set of criteria (political institutions, single citizenship, defence policy, federal monetary policy, federal justice). We think that the interactive analysis we elaborate here offers an innovative approach of comparison between federal institutions, since it combines an ancient federation, the Achaean one and two modern paradigms, from two different continents so as to have a more integrated picture about federalism worldwide.

We analyze the EU, as a case of political entity where federal structures are in an ongoing and gradual process of development since 1992 and the Treaty of Maastricht. In this point we have to acknowledge that such an analysis could be seen as a historical anachronism for some scholars. However, we have to acknowledge that our intention is not to compare the three cases in absolute terms, but under a specific set of criteria which we interpret as "federal" in a wider sense, such as their political institutions (being democratic or not, collective decision making or not etc.) the issue of equal political rights and single citizenship, the issue of Common Foreign and Defence Policy, the issue of using (or not) federal coins and finally, the issue of federal justice.

Under such a perspective, we think that the comparison of the three cases is feasible and may offer some ideas in favor of making the political and economic institutions of our modern societies more attractive to their constituents. Our findings indicate the Achaean federation 


\section{I Macrothink}

could offer a series of institutional arrangements, especially on the issue of making democracy more efficient and functional to modern democracies globally. Thus, we conclude offering some insights concerning democratization and cohesion institutional practices based on the institutional organization of the ancient Greek federation.

\section{The Achaean Federation: The Historical Background in Brief}

The Achaean federation was established sometime between 431 and 382 BCE. It come as an evolution of an older alliance of city-states of the north-western Peloponnese, a part of today's southern part of mainland Greece (Mackil, 2013, pp. 8, 46-52, 63) (Note 5).

As with the other ancient Greek federations, the main motive for its creation was defense against the kingdom of Macedonia of northern Greece, as well as Sparta and the Aetolian federation, two neighboring states. Since each state in the region of Achaea was not capable enough to protect itself only by its own means, they found that a joint provision of the public good defence could be beneficial for all city-states. This, as we will argue proved successful.

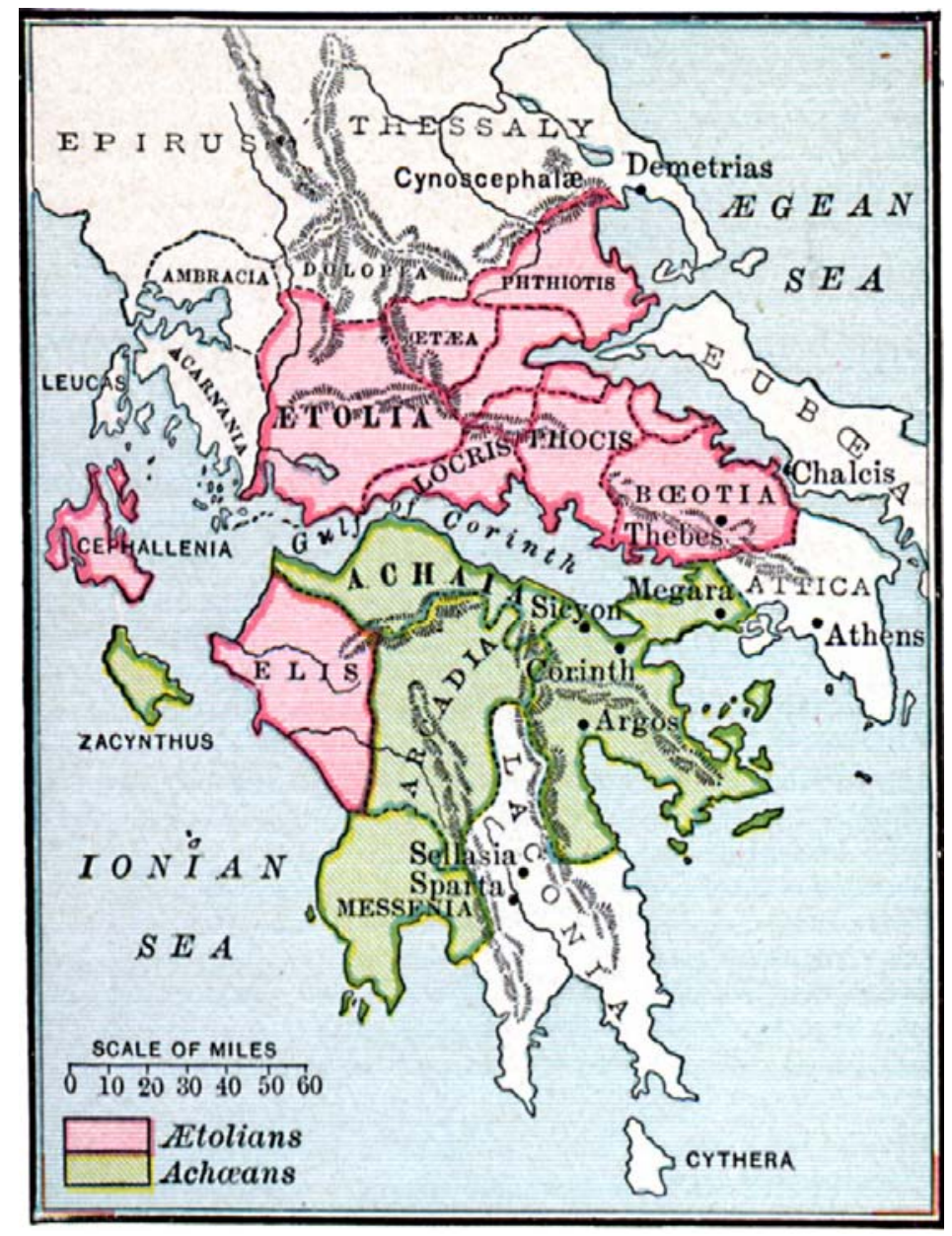

Picture 1. The Achaean (green colour) and the Aetolian state (purple colour), two neighbouring democratic federations in central/southern Greece

Source: http://etc.usf.edu/maps/pages/6100/6136/6136.htm 
Furthermore, this collaboration did not remain just to the level of a mere military alliance, but it evolved into the creation of a federal type of state. The federation increased from 10 members-city states in $280 \mathrm{BCE}$, to as many as 50 later. Gradually, after $280 \mathrm{BC}$, a series of city-states throughout northern and central Peloponnese decided willingly to become members of the newly founded regional federation, such as Sikyon, Megalopolis and Argos in 229 BC (Polybius, Hist. 2. 41; Larsen, 1972; Mackil, 2013).

The Achaean federation became a key political force in Greece, trying to balance Macedonian and Spartan power in a series of wars and shifting alliances, being successful in safeguarding its city-states independence against both powers for more than two centuries. It was abolished in 146 BCE after being defeated by the Romans, a fact which meant not only the end of the federation, but also the end of Greek independence (Badian, 1952; Oliver, 1978).

\section{Political Organisation}

The Achaean federation comprised by three main institutional bodies. The first was the federal pan-Achaean Assembly. All citizens of all constituting city-states aged 30 and above could take part in it. The federal assembly took place twice a year, first time during spring and the second time during autumn, to decide on crucial matters such as war and peace, economic policy etc. (Livy, Hist R. 29; Davis, 1978, p. 31; Mackil, 2013, p. 342).

The second major political body was the Council (Greek: Boule), a body which set up the agenda for the Assembly's meetings (Pol. Hist. 2. 46. 6, 4.7.1, 29. 23-35, 29. 24.6; Aymard, 1938, p. 155; Larsen, 1972, p. 17). The members of the Council were locally elected representatives of their homeland city-states. Thus we have, for the first time in history, a mixed democratic system of both direct (the Assembly) and representative democracy (the Boule). The third major political body, was the 10-member government executive board being democratically elected by the two pan-Achaean assemblies. This board was responsible for daily administration, with one year service.

The highest in hierarchy among the board members was called Strategos, literally meaning the General, who combined both the offices of the political head of the federation and the highest military commander of the military forces, somewhat like the de facto position of George Washington during 1776-1783, or Napoleon Bonaparte during 1798-1814. Under the General, there were also some other high ranking officials with dual jurisdictions such as the major-general. There was also the grammateus ("secretary") who may have been responsible for the "paperwork" of the federation, such as the Assembly's and the Boule's decrees and laws (Larsen, 1971, 1972, p. 188; Mackil, 2013, p. 342). In other words, this body can be interpreted as a kind of a cabinet, aiding the Strategos in his duties.

A very important institution of the federation was the isopoliteia, meaning single citizenship of its citizens, under which a citizen of one member city-state, had political, civil and property rights, if he moved to another member-city-state of the federation (Schwahn, 1931b; Mackil, 2013, pp. 255, 263, 266), a situation that clearly goes beyond today's European Union. Transferring this process to modern EU, it could mean that, for example, British people could go and stay in Germany, automatically acquiring voting rights at German 
federal elections, buy property etc. and vice versa.

Concerning the issue of federal judicial services, there were federal courts in existence which were authorized to solve criminal, civic and property rights between federal citizens (Ager, 1996). Finally, concerning defence matters, as it has already been referred, the primary reason for the establishment of the federation, was common defence strategy against the military mighty state of Macedonia in the fringes of the Greek world, which had hegemonic aspirations in southern Greece. The Achaean federation utilized heavy and light infantry troops, as cavalry regiments. The composition of these troops was a mixture of both conscript troops and professional soldiers. There were also small scale naval forces (Larsen, 1971; Scholten, 2000, pp. 107, 141).

\section{Economic Organization}

The Achaean federation was a multicurrency area: there was a parallel circulation of both federal and city-state coins, as attested to by archaeological findings (Thompson, 1939; Mackil, 2013, pp. 251-252). However, it is not certain what was the analogy of federal to city-state coins or under which procedures these coins were being minted. Most coins that have been found were made from silver (Note 6). Coins had an intrinsic value. There were federal mints working in the city-states and the capital. Local mints were issuing both local and federal coins.

Public (state) revenue sources came from: city-state contributions, customs duties levied on exports and imports, grants by the wealthy citizens in order to increase their personal reputation and political prestige, liturgies, a very special type of taxation levied on the wealthy citizens as those in democratic Athens (see Kyriazis, 2009), loans to the state offered by private investors and military plundering, an ordinary action in war periods after successful war campaigns (Xen. Hell. 5.2.6; de Laix 1973, p. 60; Scholten, 2000 pp. 103, 105; Mackil, 2013, pp. 290, 387; Economou, Kyriazis, \& Metaxas, 2015).

Another issue we take into account here is, if and to what extent, the federation was not only a monetary union, but also an economic one. Again, the available evidence is not enough, however we advance some possible answers: the existence of monetary union and the circulation of parallel currencies are evidence of the free mobility of capital within the federation. The existence of single citizenship (isopoliteia) for citizens is also a very strong evidence for the free circulation of labour. If a citizen of one member city-state had equal political rights in another, then obviously he could settle and work there without limitations. Thus, it appears that two of the main principles of today's EU, free circulation of capital and labour existed already in the Achaean federation.

In this point we offer some arguments as to why democratic federations proved to have been efficient political mechanisms in ancient Greece. Thus, we offer to this point a series of criteria which are related with the success of the Achaean federation. At first it is the issue of defense against common enemies.

The Achaean federation managed to safeguard the independence of its member city-states for about 250 years, which is a remarkable amount of time if we take into account that the 4th 
and 3rd centuries BCE in Greece were a period of harsh geopolitical competition between political entities in the wider area of Hellenism (see Fine, 1940; Larsen, 1968; Granger, 1999). The Achaeans who were forced to face a strongest enemy during the 4th and the 3rd century $\mathrm{BCE}$, Macedonia united together, thus increasing their military potential against strong enemies. They simply implemented the motto "united we stand, divided we fall". And this proved successful since not only the federation managed to preserve its independence for two and half centuries, but also to expand its influence through its capable generals such as Aratus of Sicyon and Philopoemen (Plutrach, Life of Aratus; Walbank, 1933; Errington, 1969).

Secondly, it is the issue we have already referred to, the incorporation of new member city-states into the federal structures on a volunteer basis. The Achaean federation grew from its original 12 members to more than 40, comparable to the growth of the USA from its original 13 states to 50, and the EU from 6 in 1957 countries to 28. This is a characteristic of all successful federations, the voluntary participation instead of using power, dominance and coercion (Note 7). Furthermore, no Greek democratic federation collapsed internally because of its citizen's dissatisfaction.

The reason of the abolishment of federalism in ancient Greece is related with Roman expansionism and internal Greek civil strife that weakened the position of Greek political entities, meaning the independent city-states (Athens, Sparta etc.), the federal states (such as the most advanced of them, the Achaean, the Aetolian and the Boeotian cases) and the Hellenistic Kingdoms such as Macedonia against a formidable enemy, the Roman Republic.

Lastly, economic success or "efflorescence" according to Ober (2015). This is related to attraction. If a federation offers economic advantages and is performing well, new members would like to join. While we don't possess exact statistics for the ancient world, there are substantial indicators that point to economic growth and good economic performance. One is based on Mackil's (2013, p. 257) argument according to which "micro-regional interdependence" among federal city-states proved successful, since the abolition of barriers between city-states and the rise of commercial activity and transactions promoted further the efficient transfer and exchange of goods from different areas of the federation (maritime, mountainous and agricultural lands) to each other, thus being beneficial to them in welfare terms. Thus according to all three criteria proposed, the Achaean federation was successful.

The last criterion as to the evaluation of the success of a federation can be used also for modern would-be federations such as the EU. Concerning economic performance, the EU was successful for the period from 1957 up to the 2008 crisis, showing strong economic growth, low level of unemployment etc., although these macroeconomic figures worsened after 2008, especially for as far as the southern EU member-states are concerned (Spain, Italy, Portugal, Greece, Cyprus).

The combination of a missing external threat and less satisfactory economic performance has led to growing euroscepticism while there are many who argue against the democratic deficit of the EU since its institutional bodies such as the European Commission (with the exception of the European Parliament) are not elected by its citizens. Nor are citizens involved in any way in decision-making, concerning major issues that the EU faces currently, such as for 
example, terrorism and immigration.

\section{The Institutional Set up of Federations: A Comparison}

Since the institutional setup of the EU is relatively well-known, we will present the main institutions of the two federations in Table 1. Many would not consider the EU as being a true federation, with some reason, since the EU lacks a constitution and a European citizenship. Such an attempt, for the establishment of an EU constitution, was voted down by the national referenda in France and the Netherlands and final abandoned in 2007.

But the European Founding Fathers, R. Schuman and J. Monnet, A. Spinelli, K. Adenauer etc. had as their ideal the transformation of the then European Common Market of 1957 into a true European federation. Table 1 presents in the first row a general overview of a series of institutional criteria of the Achaean Greek proto-federation in comparison to the modern EU. We consider such criteria to be of major importance in order for a political entity to be characterized as a federation, such as the existence or not of a monetary union and single citizenship. Table 1 shows that the Greek proto-federation had established an institutional framework of values and principles such as political democratic structures, a regime of equal political rights, common foreign policy, common currency and common federal justice.

Table 1. A comparative analysis of the institutional framework of the Achaean federation in relation to India and the EU

\begin{tabular}{|c|c|c|c|c|c|c|c|}
\hline State & $\begin{array}{c}\text { Member } \\
\text { states/provinces }\end{array}$ & Capital & $\begin{array}{l}\text { Main institutional } \\
\text { organs intended for } \\
\text { taking political } \\
\text { decision and executive } \\
\text { power }\end{array}$ & $\begin{array}{l}\text { Regime of } \\
\text { equal } \\
\text { political } \\
\text { rights }\end{array}$ & $\begin{array}{l}\text { Common } \\
\text { Foreign and } \\
\text { Defence } \\
\text { Policy }\end{array}$ & $\begin{array}{c}\text { Local and } \\
\text { federal coins }\end{array}$ & $\begin{array}{c}\text { Federal } \\
\text { justice }\end{array}$ \\
\hline $\begin{array}{l}\text { Achaean } \\
\text { Federation }\end{array}$ & $\sim 40$ & Aegion & $\begin{array}{c}\text { Federal Assembly } \\
\text { Federal Council } \\
\text { Federal (10 } \\
\text { member) Governing } \\
\text { board } \\
\text { Strategos (General) } \\
\text { Head of the State }\end{array}$ & $\nabla$ & $\nabla$ & $\begin{array}{c}\mathrm{LC}+\mathrm{FC} \\
\text { (both local } \\
\text { and federal } \\
\text { coins) }\end{array}$ & $\nabla$ \\
\hline $\mathbf{E U}$ & $28^{*}$ & Brussels* & $\begin{array}{l}\text { European Commission } \\
\text { European Parliament } \\
\text { Council of Ministers } \\
\text { European Summit } \\
\text { (heads of state and } \\
\text { governments) }\end{array}$ & $\begin{array}{l}\text { No single } \\
\text { citizenship } \\
\text { throughout } \\
\text { the EU }\end{array}$ & $\begin{array}{c}\text { CFSP } \\
\text { EU } \\
\text { Battlegroups }\end{array}$ & $\begin{array}{c}(\mathrm{LC}+\mathrm{FC}) \\
(\mathrm{ECB})\end{array}$ & $\begin{array}{l}\boldsymbol{\nabla} \\
\text { Court of } \\
\text { Justice of } \\
\text { the EU }\end{array}$ \\
\hline
\end{tabular}

\section{Explanations:}

LC: local coin ; FC: federal coin, $\quad \mathbf{\nabla}$ : institution in force, $\quad *$ : institution in development

Source: Interactive analysis based on the findings of sections 2-5 for the Achaean federation and Moussis (2008) and Peterson, and Shackleton (2012) for the EU. 
Both cases present democratic political structures (column 4), being provided for the safeguarding of political rights and justice (column 8). They both possess a "mixed" system of usage of both local and federal coins (column 7). When it comes to the EU, the euro, which is under the aegis of the European Union Central Bank (ECB) and it is utilized by the Eurozone members of the EU, it cannot be considered yet a "federal currency". Euro is in usage only by the 19 Eurozone member-states.

Furthermore, the Greek federation may be regarded as superior to the EU as far as foreign policy and defence issues are concerned (column 6). This is because, even though the EU has already introduced the Eurocorps and the EU Battlegroups as military means in order to achieve an effective Common Foreign and Security Policy (CFSP), it still needs further steps so as to implement a truly effective and reliable CFSP (Hartley 2003; Metaxas \& Economou, 2012) and possibly, an "European Defense Union" (Kollias, 2008). Finally the Achaean federation introduced common administration, common and parallel currencies, federal courts of justice and single citizenship called isopoliteia e.g. a citizen of a city-state having citizen's rights in the other city-states, a situation that does not exist in the EU (column 5).

\section{The Working of Democracy}

The federations we examine are democratic, although to a different degree, depending on their political structure and voting procedures. Some federations of past were non, or semi-democratic. For example, the ancient Greek Thessalian federation (Wade-Gury, 1924; Larsen, 1960) and China during the Han and T'ang dynasties had some federal structures but not democratic (Edwards, 2009; Chan \& Laffargue, 2012) while the United Provinces (Dutch Republic) could be characterized as "a democratic head upon an oligarchic body" (Halkos \& Kyriazis, 2005, p. 61). The Soviet Union and Yugoslavia were federal states prior their breaking apart, but not democratic.

In today's world, the issue of how democratic a state (whether federal or not) is gains again in importance, in view for example, of rising undemocratic behavior of some governments, political instability, euroscepticism, the rise of extremist parties etc.

To analyse how democratic federations are, we consider focus on the degree of their democratization, which means that we are looking for the higher involvement of their citizen's in policy and decision making, having in mind the origins of democracy in ancient Greece, as well as some procedural characteristics having to do with legal and property rights protection. Legal equality precedes democracy in ancient Greece and was present in the Achaean federation, as well as in the EU we examine here. In this respect, there are not substantial differences, apart from procedural points having to do with the legal system, as for example, trial by juries (as was the case in the Achaean federation and in the Anglo-Saxon tradition) or not.

Political equality varies though. Ancient Greeks thought that political equality meant that all the state positions should be open to all citizens, eg. in the Athenian democracy, from the highest, the head of state (called the eponymos archon), the 10 generals (both for the land forces and the navy) the "finance ministers" and the magistrates, both political and religious. 
Some positions were covered by lot (those not requiring specific knowledge and ability), others (those requiring "specialized knowledge and skills) like the generals and the finance ministers, but also some lesser magistrates, were covered by election by the assembly, either at city-state level, or federation level. According to Pritchard (2014, p. 14), about 100 magistrates were elected in the 4th century Athens.

In the EU the post of the President of the EU is not open to all citizens, since it is covered according to negotiations as to the candidates between the national governments. In fact, the only elected body in the EU is the European parliament (EP), which has limited competences (compared to national parliaments) although they have increased during the preceding years.

The EP is thus not a true legislative body, since European legislation is initiated by the European Commission, goes through the Council'(s) of Ministers and comes last to the EP. The EP has limited competence in shaping the EU's budget, being able to change only the so-called "non-obligatory" expenses. Also, it votes for the President of the Commission, but being able to approve or reject the candidates proposed by the national governments. So, concerning political equality (as we have analysed it, all political posts being open to every citizen are being covered by election) the Achaean federation was more democratic than today's EU.

Another aspect of democracy, as practiced in ancient Greece at city-state and federation level, which they considered perhaps the most fundamental, was citizen's participation in policy and decision making. They coined a new term for it, isegoria, meaning equality of speech and equality to propose policy measures on any and all issues, for example, foreign policy (alliances, peace, war declaration, acceptance of new members in the federation) economic policy, taxation, the choice and the finance of public goods. Such a case was for example Themistocles Naval Law of $483 / 2 \mathrm{BC}$, to build and finance the fleet that won subsequently the battle of Salamis (Kyriazis \& Zouboulakis, 2004), or Nikophon's Monetary Law (476/5 BC) that permitted the parallel circulation of currencies in Athens (Engen, 2005; Ober, 2008). After debating the issues, the Assembly of citizens voted and the proposal was accepted or rejected. Isegoria thus was the cornerstone of ancient direct democracy (Hansen 1999).

In modern democracies, this takes the form of citizen's initiatives that lead to referendums with legally binding outcomes. Some modern federations practice them at all levels and for all issues (for example Switzerland and New Zealand), others at state level and for some issues (as for example the USA and Germany). For example, in German Länder, financial matters are exempted from popular initiatives, while they are included in some American states such as California, with the famous Proposition 13 that prohibited the increase of property taxes (Cronin, 1999).

In the EU initiatives have not a binding character to the EU policymakers. The Lisbon EU Treaty foresees the possibility of European level referendums. Since April 12012 citizens can collect 1 Mio signatures from at least a quarter of the EU Member States in order to ask the European Commission to propose legislation in areas that fall within its competence. Practically it is required that the organizers of a citizens' initiative must consist of at least 7 EU citizens, who are residents in at least 7 different Member States. They should manage in 
one year to collect the necessary support of one Mio signatures.

Then, they can participate in a hearing at the European Parliament. Finally, the Commission will have 3 months to examine the initiative and decide how to act on it. This actually means that the outcome of an initiative is not legally binding, which further means that it has only consultive character. Thus, again, in this respect, the Achaean federation was more democratic than the two modern ones we analyse here (Note 8).

A last criterion important for federation, both political and economic, is single citizenship. Single citizenship, as it has already been analysed, means that a citizen of one member-state, being at the same time a citizen of the federation, can "move" his political and voting rights from one member state to another. A citizen of the city-state of Patras, if he moved to Megalopolis, could participate in the Assembly of Megalopolis, another city-state of the Achaean federation. This is not valid (at least yet) for the EU which lacks the concept of European citizenship, linked to the rejection of the European constitution by referendums in France and the Netherlands in 2007 as we have already mentioned before. Thus, an Italian for example, who moves into Finland, has not the right to vote for German national elections (although, after living for a specific period of time, he could vote for city or local elections).

Federations are characterized also according to their economic structure. We stated above, that single citizenship is also an economic criterion for federations, because it is linked to the free movement of labour. Free movement of labour is one of the main principles of federations and applies to all four cases we examine here. As we have argued, the EU is the exception where there is a "break" between the free movement of "political rights" (as in the Achaean federation) which is not valid in the EU and the free movement of "economic rights", labour and capital, which is valid in the EU.

Furthermore, both cases we examine here are monetary unions to some extent, where the freedom of capital movements applies, but with some differences. Within the EU, the EMU applies to 19 members, while the other 9 members have their own currencies. The Achaean federation had a parallel circulation of federal and "national" city-state coins. The differences as to the existence and to what degree of a fiscal union, are more marked. Fiscal union comprises two basic elements: the height of the fiscal budget, which is the main indication as to the financing (and the existence) of common policies, and the degree of harmonization of fiscal policies, as indicated by common tax rates, tax bases, or not.

It has been estimated (Economou \& Kyriazis, 2016) that the Achaean federal budget was at least 900 talents in $217 \mathrm{BCE}$, which is a very substantial sum, comparable to that of the strong Athenian economy's in the 330's, which had achieved an annual state budget of as high as 1200 talents (Amemiya, 2007; Ober, 2008) a very substantial amount of money for that era. This sum mainly had to do with high military expenditure, which was the main item of state's expenditure over time, up to the second half of the 19th century, from which point on, states started to implement new policies (requiring substantial expenditure) like education, health and social security. This difference shows that only few policies are financed to a low degree at EU level, compared to other federations. 
In fact, the only fully integrated policy, financed exclusively at EU level, is the Common Agricultural Policy. At European level, the subsidiarity principle, e.g. the co-financing of common policies at the federal and national levels, or the financing levels, seem to be stronger than at the other federations. It must also not be forgotten, that defense is one of the main policies financed exclusively at the federal level for old and present day federations (usually about 2-3\% of GDP) but not for the EU, which lacks European Armed Forces and a Common Defense Policy.

Lastly, our two cases have common market where the economic liberties, free movement of goods and services, labour and capital apply.

\section{Concluding Remarks}

Our discussion on some aspects of federations is, we believe, important because it offers a basis for the evaluation of the durability of federations. The more democratic (and thus, legitimate in the eyes of their citizens) and cohesive (and thus indicating a higher community of interests and common welfare), the more durable a federation will be (or was).

The most institutionally organized ancient Greek democratic proto-federations such as the Achaean and the Aetolian ones lasted more than 250 years, as against, for example, Czechoslovakia's only 45 years (1945-1990), the Soviet Union's 68 (1922-1990) or the EU's just 24 (1992-2016). The European Union was established in 1992 with the Treaty of Maastricht. However, in the last years it shows signs of stress. India which is the most populous federal state (approximately 1,2 billion people) goes back to 1949, which means that there are 66 years as far as the Indian federal experience is concerned.

As we have already argued, the ancient Greek federations were bottom-up voluntarily ones. City-states joined voluntarily after a vote in the popular assembly in the city-state in favour of joining and a vote in the assembly of the federation to be accepted or not. The ancient Greek democratic federations, applying direct democracy at all levels, were more democratic than most present federations, with the exception of the Swiss. Thus, they enjoyed a very high degree of legitimization by their citizens (the opposite to the present day EU) which was the base for their durability.

Our argumentation here is also verified by the findings of de Figueiredo and Weingast (2005) who argued that the two basic principles that must exist for federal institutions to emerge are: a) there must be gains by the participation in a federation b) these gains cannot be found in an alternative institutional and political form of organization. The citizens of the Greek federations and more specifically, in our case, the Achaean one, were willing to fight to preserve them because they perceived a community of interest and an increased personal welfare (mainly due to no barriers in commercial activity between city-states, which benefited all sides) from belonging to them (Mackil 2013; Economou, Kyriazis, \& Metaxas, 2015; Economou \& Kyriazis, 2016).

Thus, our policy suggestions for the EU, if it is to progress towards becoming a true federation, is to introduce more democratization in the form of binding popular initiatives and referendums (direct democracy) and the direct election of its political leadership (such as the 


\section{Macrothink}

President of the European Union and the European Union commissioners). To increase cohesion, the EU has to increase its federal budget intended for redistribution of money so as to implement social policies, such as economic relief to special social groups that really need some kind of financial aid and in general, to establish a higher European budget for regional and social policies as a whole. Finally, a common external policy-defence policy must be implemented, the so-called Common Foreign and Security Policy (CFSP) which is linked to steps for the further integration of the institutions of the EU.

The introduction of direct democracy elements (binding referenda after popular initiatives) should be adopted in the EU in a more regular basis. Referenda and popular initiatives are already being practiced in more and more countries, like the USA, Brazil, Uruguay, Switzerland, Germany, New Zealand, Australia, etc. They must become more frequent in the EU so that government policymakers' decisions to have a more legitimacy in the eyes of the Union's citizens. The following figure depicts the main core of our proposal for a more functional and cohesive EU.

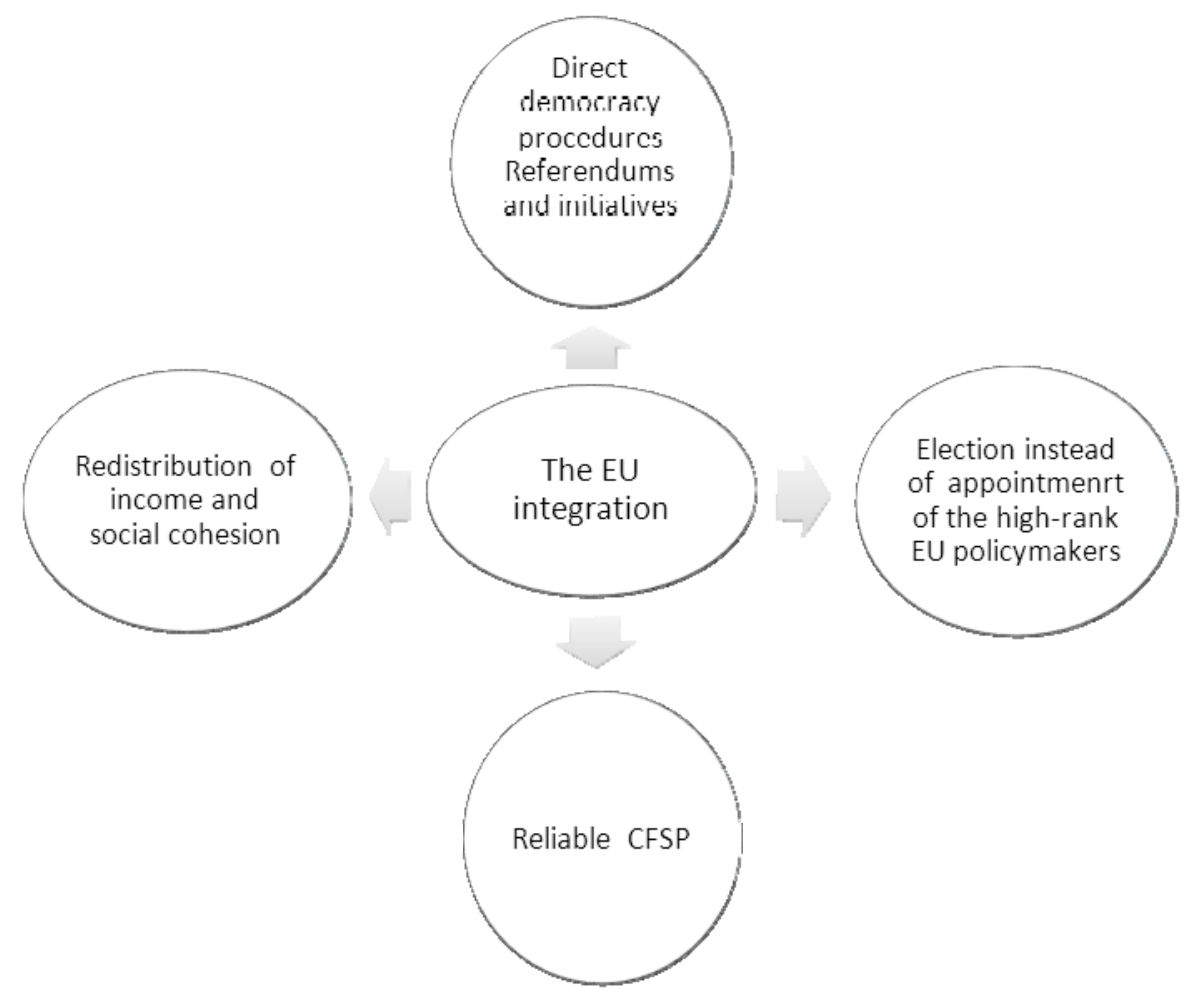

Figure 1. A benchmark of policies in favour of the further EU integration based on the Achaean paradigm

With this paper, we hope that we contribute in the ongoing discussion globally, as far as the improvement of the quality of democracy is concerned.

\section{Acknowledgements}

The authors wish to thank Vincent Gabrielsen for his helpful comments which led to the 
significant improvement of this work.

\section{References}

Ancient authors

Aristotle "Politics", (Arist. Pol.).

Herodotus "History”, (Her. Hist.).

Livy "Histoty of Rome”, (Liv. Hist. R.)

Plato "Republic" (Pl. Rep.).

Plutarch "Life of Aratus", (Pl. Ar.).

Polybius "Histories" (Pol. Hist.).

Thucydides "History" (Funeral Oration), (Thuc. F.).

Xenophon "The Polity of the Athenians", (Xen. Pol.).

Xenophon "Hellenica", (Xen. Hell.).

Modern authors

Amemiya, T. (2007). Economy and economics in ancient Greece. London: Routledge.

Ager, S. (1996). Interstate relations in the Greek world 337-90 BC. Berkeley: University of California Press.

Aymard, A. (1938). Les assemblées de la confédération Achaienne: etude critique d'institutions et d'histoire. Bordeaux: Féret \& Fils.

Badian, E. (1952). The Treaty Between Rome and the Achaean League. The Journal of Roman Studies, 42(1/2), 76-80. http://dx.doi.org/10.2307/297516

Buckler, J. (1980). The Theban hegemony, 371-362 B.C. Harvard: Harvard University Press.

Chan, K. S., \& Laffargue, J. P. (2012). Foreign Threats, Technological Progress and the Rise and the Decline of Imperial China. Pacific Economic Review, 17(2), 280-303. http://dx.doi.org/10.1111/j.1468-0106.2012.00583.x

Chinard, G. (1940). Polybius and the American Constitution. Journal of the History of Ideas, 1(1), 38-58. http://dx.doi.org/10.2307/2707009

Cronin, T. E. (1999). Direct democracy: the politics of initiative referendum and recall. Harvard: Harvard University Press.

Davis, R. S. (1978). The federal principle: a journey through time in quest of meaning. Berkeley Los Angeles and London: University of California Press.

de Figueiredo, R. J. P., \& Weingast, B. (2005). Self-enforcing Federalism. Journal of Law, 
Economics and Organisation. 21. 103-135. http://dx.doi.org/ 10.1093/jleo/ewi005

Laix, R. A. (1973). The Silver Coinage of the Aetolian League. Californian Studies in Classical Antiquity, 6. 47-75. http://dx.doi.org/10.2307/25010647

Economou, E. M. L., Kyriazis, N., \& Metaxas, T. (2015). The Institutional and Economic Foundations of Regional Proto-federations. Economics of Governance, 16(3), 251-271. http://dx.doi.org/10.1007/s10101-014-0155-4

Economou E. M. L., \& Kyriazis N. (2016). The Emergence and the Development of the Achaean federation. Lessons and institutional proposals for modern societies. Evolutionary and Institutional Economics Review. Retrieved from http://link.springer.com/article/10.1007\%2Fs40844-015-0028-8

Edwards, R. A. (2009). Federalism and the Balance of Power: China's Han and Tang Dynasties and the Roman Empire. Pacific Economic Review, 14(1), 1-21. http://dx.doi.org/10.1111/j.1468-0106.2009.00430.x

Engen, D. (2005). Ancient Greenbacks, Athenian Owls, the Law of Nicophon, and the Greek Economy. Historia, 54, 359-381.

Errington, R.M. (1969). Philopoemen. Oxford: Clarendon Press.

Fine, J. V. A. (1940). The Background of the Social War. The American Journal of Philology, 61(2), 129-165.

Grainger, J. D. (1999). The league of the Aitolians. Leiden and Boston: Brill Academic Pub.

Gummere, R. M. (1962). The Classical Ancestry of the United States Constitution. American Quarterly, 14(1), 3-18. http://dx.doi.org/10.2307/2710223

Halkos, G., \& Kyriazis, N. C. (2005). Naval Revolution and Institutional Change: the Case of the United Provinces. European Journal of Law and Economics, 41-68. http://dx.doi.org/10.1007/s10657-005-5275-

Hansen, M. H. (1999). The Athenian Democracy in the Age of Demosthenes. London. Bristol Classical Press.

Hartley, K. (2003). The Future of European Defence Policy: An Economic Perspective. Defence and Peace Economics, 14(2), 107-115. http://dx.doi.org/10.1080/10242690302921

Kollias, C. (2008). A Preliminary Investigation of the Burden Sharing Aspects of a European Union Common Defence Policy. Defence and Peace Economics, 19(4), 253-263. http://dx.doi.org/10.1080/10242690802164777

Kyriazis, N., \& Zouboulakis, M. (2004). Democracy, Sea Power and Institutional Change: An Economic Analysis of the Athenian Naval Law. European Journal of Law and Economics, 17(1), 117-132. http://dx.doi.org/10.1023/A:1026342010780

Kyriazis, N. (2009). Financing the Athenian State: Public Choice in the Age of Demosthenes. European Journal of Law and Economics, 27(2), 109-127. 
http://dx.doi.org/10.1007/s10657-008-9081-7

Larsen, J. A. O. (1960). A New Interpretation of the Thessalian Confederacy. Classical Philology, 55(4), 229-248. http://dx.doi.org/10.1086/364511

Larsen, J. A. O. (1968). Greek federal states. Their institutions and history. Oxford: Clarendon Press.

Larsen, J. A. O. (1971). The Rights of Cities within the Achaean Confederacy. Classical Philology, 66, 81-86.

Larsen, J. A. O. (1972). A Recent Interpretation of the Achaean Assemblies. Classical Philology, 67, 178-185.

Mackil, E. (2013). Creating a common polity. Religion, economy, and politics in the making of the Greek koinon. Berkeley, Los Angeles and London: University of California Press.

Metaxas, T., \& Economou, E. M. L. (2012). Security Policy in the European Union and the United States through the Issue of their Defence Expenditures. Journal of Global Analysis, 3, 58-81.

Moussis, N. (2008). Access to European Union: Law, economics policies. Rixensart: European Study Service.

Ober, J. (2008). Democracy and knowledge. Innovation and learning in Classical Athens. Princeton: Princeton University Press, 2008.

Ober, J. (2015). The rise and the fall of Classical Greece. Princeton: Princeton University Press.

Oliver, J. H. (1978). Panachaeans and Panhellenes. Hesperia: The Journal of the American School of Classical Studies at Athens, 47(2), 185-191.

Payne, S. B. (1996). The Iroquois League, the Articles of Confederation, and the Constitution. William and Mary Quarterly 3rd Series, 53(3), 605-620. http://dx.doi.org/10.2307/2947207

Peterson, J., \& Shackleton, M. (2012). The institutions of the European Union. Oxford: Oxford University Press.

Pritchard, D. (2014). The Public Payment of Magistrates in Fourth-century Athens. Greek, Roman and Byzantine Studies, 54, 1-16.

Richard, C. J. (2009). Greeks \& Romans bearing gifts: how the ancients inspired the Founding Fathers. Lanham: Littlefield Publishers Inc.

Scholten, J. B. (2000). The politics of plunder: Aitolians and their koinon in the Early Hellenistic era, 279-217 BCE. Berkeley and Los Angeles: University of California Press.

Schwahn, D. (1931). Das Burgerrecht der Sympolitischen Bundessaaken Beiden Griechen. Hermes, 66, 97-118.

Singh, N. (2008). Holding India Together: The Role of Institutions of Federalism. MPRA 
Paper No. 12432, Munich Personal RePEc Archive, 2008. Retrieved from https://mpra.ub.uni-muenchen.de/12432/1/MPRA_paper_12432.pdf

Thompson, M. (1939). A Hoard of Greek Federal Silver. Hesperia: The Journal of the American School of Classical Studies at Athens, 8, 116-154.

Wade-Gery, H. T. (1924). Jason of Pherae and Aleuas the Red. The Journal of Hellenic Studies, 44(1), 55-64.

Walbank, F. W. (1933). Aratos of Sicyon. Cambridge: Cambridge University Press.

\section{Notes}

Note 1. The first ever discussion on the merits and demerits of different political regimes is to be found in the fictitious discussion of noble Persians, as to which is the best. Thus, Herodotus is not only the father of history, but also of political science (Her. Hist. III.80-82).

Note 2. We owe this comment to Vincent Gabrielsen (Kopenhagen University).

Note 3. On the influence of the Greek federalism on the American Founding Fathers, as seen also through the Federalist papers, see among others Chinard (1940), Gummere (1962), Payne (1996) and Richard (2009).

Note 4. For the Aetolian and the Boeotian federations Larsen (1968), Buckler (1980), Granger (1999), Mackil (2013) and Economou, Kyriazis and Metaxas (2015) offer detailed analyses.

Note 5. We reach to such an estimation through Mackil (2013, pp. 46-52) who she is based on Xen. Hell. 4.6.2-4 who mentions an alliance of the Achaean federal state with Sparta during the Peloponnesian war (431-404 BC). Mackil in these pages offers additional references by both modern and ancient authors.

Note 6. http://www.forumancientcoins.com/gallery/thumbnails.php?album=1983

Note 7. Not all federations are formed on a voluntary bottom-up procedure, as was the case with the Soviet Union. In the case of India, explicit military force was used to annex the state of Hyderabad into the union (Singh 2008) and as the American Civil War demonstrates, states are not always free to secede.

Note 8. http://www.europarl.europa.eu/atyourservice/en/20150201PVL00039/Citizen's-initiative

\section{Copyright Disclaimer}

Copyright for this article is retained by the author(s), with first publication rights granted to the journal.

This is an open-access article distributed under the terms and conditions of the Creative Commons Attribution license (http://creativecommons.org/licenses/by/3.0/). 